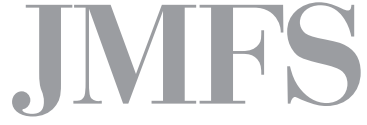

Journal of Management and Financial Sciences
Volume XII

Issue 37 (June 2019

pp. $61-73$

Warsaw School of Economics

Collegium of Management and Finance

\title{
Assessment of public expenditure on education and the impact of revenues: the case of Moldova
}

\begin{abstract}
Investment in human capital is a key strategic concept for the economy and for future development of a country. Therefore, public expenditure on education determines a major point in countries like Moldova, where the education is financed from public funds predominantly. Theories show that the link between expenditures and revenues is inevitable in most of the cases. This study attempts to approach two angles of spending in education: the first is to study and analyse public expenditures in education and in what budget proportions they are spent, and the second is to find out whether there exists a relationship between expenditures in education and government revenues; if yes, to what extent the revenues would have an impact on the expenditures in education. The Autoregressive Distributed Lag model was used in order to find the impact of revenues on expenditures in education. The model was tested for stability, heteroskedasticity, correlation, and normality. The results of the study show that the expenditures on education in the Republic of Moldova lack stability in relation to the economy and that the significant impact from government revenues determines the expenditures in the short and long run. The research is a contribution to the enhancement of public expenditure policy in education taking into consideration the limits imposed from the revenues side, and it may guide governments for better decision-making policies.
\end{abstract}

Keywords: fiscal policy, policy making, revenue, education expenditures, public expenditure, education finance

JEL Classification Codes: E62, G28, H20, H52, H72, I22 


\section{Introduction}

Education is one of the main nexuses between the economy, human capital and political power. In today's globalised economy, it is the key to the increase in national wellbeing, leading to innovation and creativity. Governments all over the world strive to have a skilled population and achieve sustained economic growth, thus, the focus on investing in education is a priority. Consequently, there is a need for resources to finance the expenditures on education. Therefore, one of the main determinants in public expenditures for education still from the government side remains to be revenues.

By researching the literature regarding the relationship between government revenues and expenditures, relevant theories could be distinguished. The main prominent theories and analysis in the literature are expressed in the works of Friedman [1978] and Buchanon and Wagner [1978], which are focused on the unidirectional causality from government revenues to expenditures. Peackok and Wiseman $[1961,1979]$ detected that increases in government expenditure generate increases in revenues. Musgrave [1966], Barro [1979] and Mettzer and Richard [1981] refer to the fiscal synchronization hypothesis that a bilateral causality exists between expenditures and revenues. As for Baghestany and Mc Newn [1994] for example, they show that government expenditures and revenues are determined by long run economic growth, therefore, no causal relationship is expected.

These assumptions are followed concretely by studies with comprehensive and various results, depending on the economy and policy of a state. Therefore, with notable demonstrations and a specific methodology among the researchers there may be mentioned Ravinthirakumaran [2011], who conducted a study on the case of Sri Lanka with the help of co integration and error correction modelling framework. The results obtained indicated the existence of a bidirectional causality between government revenues and expenditures. Aregbeyen and Insah [2013] investigated the relationship between government expenditures and revenues for Nigeria and Ghana, using the Dynamic Ordinary Least Squares methodology, and consequently there was established the existence of the prevalence of the fiscal synchronization hypothesis.

Edita and Mbazima [2008] researched the revenue-expenditure causality in Namibia with the help of co-integrated vector autoregression methods. As a result, there was found the existence of a unidirectional causality from revenues to expenditures. Mehrara and Rezaei [2014] in researching the Iran government revenues and expenditures found the unidirectional causality running from government revenues to government expenditures.

Luković and Grbić [2014] investigated the case of Serbia using Toda-Yomomoto long-run non-causality method. The result was a unidirectional causal relationship from government expenditures to government revenues.

The causality between revenues and expenditures in public finance is widely studied in the literature. As the studies show, there is a relationship that confirms the theoretical dependence of the government revenues and expenditures. Although it has a special relevance for 
policymakers, in the Republic of Moldova this point of view is much less exposed, specifically in the educational sector.

Therefore, one of the purposes of the present study is to find out what is the relationship between public expenditures, specifically expenditures on education and public revenues and to find whether there is an impact created from the side of government revenues on the total expenditures made by the government on education.

Another purpose is to analyse the public expenditures in education in the Republic of Moldova. It will help to understand their importance for the educational sector and to find out the past trends and proportions, thus, avoiding the budget deficit and the inconclusive policies in the future.

\section{The evolution and analysis of the expenditures on education in the Republic of Moldova}

Public expenditures on education are an essential element in social expenditures. At the same time, the highest share of expenditures within the National Public Budget in the Republic of Moldova belongs to Social Expenditures. This is confirmed by the expenditures share in Gross Domestic Product (Figure 1). Social expenditures hold the highest share in Gross Domestic Product of approximately 19-31\%.

Figure 1. Social and economic expenditures share in Gross Domestic Product during 2000-2015 (\%)

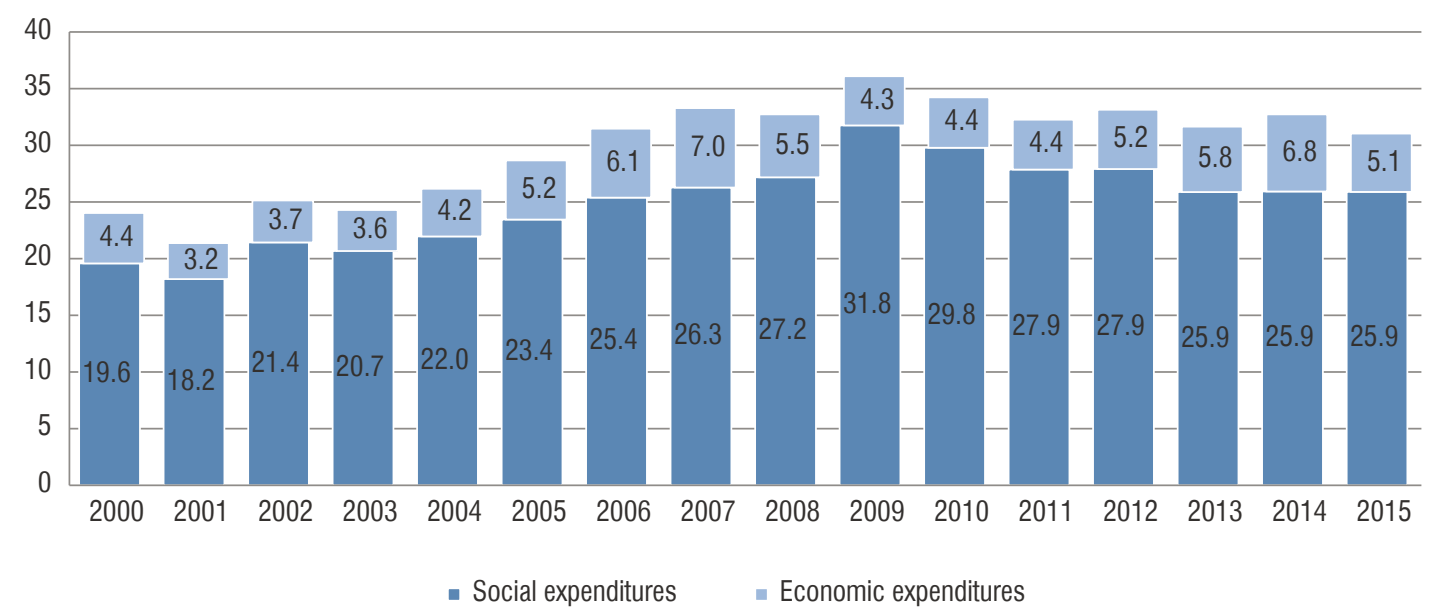

Source: own elaboration, based on the data reports published by the Ministry of Finance of the Republic of Moldova. Retrieved from: http://old.mf.gov.md/transparenta/catalog_date_deschise [accessed: 28.01.2019].

Beginning with 2000, social expenditures tended to have a slightly upward trend until 2013, and from 2013 to 2015 they showed a much more stable weight in Gross Domestic Product of 25.9\%. These shares are determined by factors both from the side of Gross Domestic Product 
and from the side of expenditures, like a decrease in economic production, international trade, investments, budgetary revenues, etc. In the second place in the share in Gross Domestic Product there are economic expenditures followed by other expenditures, which account for a smaller share in Gross Domestic Product.

In the functional classification of the budget expenditures applied in the Republic of Moldova until 2015, the social expenditures are grouped into: education expenditures; health expenditures; culture, art, sport and measures for the youth and social assistance, as well as security expenditures. As for expenditures on education, these include expenditures like: on preschool, primary, secondary, higher, postgraduate education, expenditures on courses and institutions, on personnel training, etc. [Ordinul, 2008]. Beginning with 2016, the structure of the budget classification is changed and takes another form, as claimed by the order of the Minister [Ordinul, 2015].

According to the weight in the total social expenditures (Figure 2), a special place is distinguished by health expenditures and the expenditures on education that make up the most of the social expenditures of about $50 \%$. These are followed by the expenditures on social assistance and security and culture, art and sport measures for the youth.

\section{Figure 2. Social expenditure components share in total social expenditures during 1995-2015 (\%)}

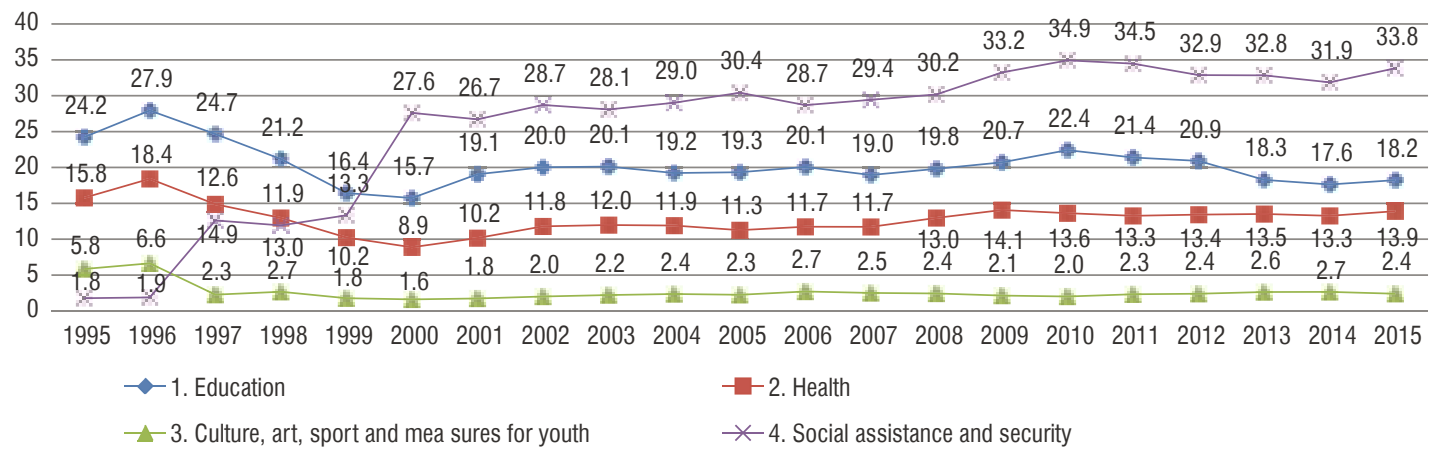

Source: own elaboration, based on the data reports published by the Ministry of Finance of the Republic of Moldova and the Statistical Year Book of the Republic of Moldova (2002), p. 494, data compiled for 1995-1999. Retrieved from: http://old.mf.gov. $\mathrm{md} /$ transparenta/catalog_date_deschise; http://www.statistica.md/pageview.php?l=ro\&id=2193\&idc=263 [accessed: 28.01.2019] .

As a basic pillar, spending on education is an important instrument of the state for better development in the future. The expenditures on education account for almost $20 \%$ of total social expenditures, with a small deviation of 1 to $2 \%$ until 2015 . However, over the years under the review, there was a rapid decline in the expenditures beginning with 1996, up to 2000 as a share in total social expenditures. Since 2000 a much more stable situation has been noticed, although from 2010 to 2015 the expenditures on education show a slight decrease in weight. 
Different factors, like insufficient funds, a reduced number of students, a reduced number of institutions available, ${ }^{1}$ etc., ${ }^{2}$ have contributed to the decrease in the share of expenditures on education over the years.

Of all the public education expenditures, most were executed within the Budget of Territorial Administrative Units, followed by the State Budget (Table 1). However, beginning with 2000, much of the expenditures on education were made within the State Budget (about 40\%). Until 2015 this weight reached a value of $25.6 \%$. The Budget of Territorial Administrative Units expenditures reached $74.4 \%$ of total expenditures on education. In comparison to the preceding years, the expenditures in the State Budget and the Budget of Territorial Administrative Units were increasing. Only for the State Budget in 2009 and 2013 a sharp decrease in expenditures was observed.

Table 1. Education expenditures by total share and growth rate (last year $=100$ ) for State Budget (SB) and the Budget of Territorial Administrative Units (BT) during 2000-2015 (\%)

\begin{tabular}{|c|c|c|c|c|c|c|c|c|c|c|c|c|c|c|c|c|c|}
\hline \multicolumn{2}{|c|}{ Index } & 2000 & 2001 & 2002 & 2003 & 2004 & 2005 & 2006 & 2007 & 2008 & 2009 & 2010 & 2011 & 2012 & 2013 & 2014 & 2015 \\
\hline \multirow{2}{*}{ Share } & SB & 40.0 & 36.4 & 35.6 & 36.3 & 36.0 & 36.4 & 35.2 & 34.4 & 34.2 & 31.1 & 30.1 & 30.1 & 29.8 & 25.7 & 24.6 & 25.6 \\
\cline { 2 - 41 } & BT & 60.0 & 63.6 & 64.4 & 63.7 & 64.0 & 63.6 & 64.8 & 65.6 & 65.8 & 68.9 & 69.9 & 69.9 & 70.2 & 74.3 & 75.4 & 74.4 \\
\hline \multirow{2}{*}{ Growth } & SB & - & 13.6 & 32.1 & 21.4 & 16.4 & 26.1 & 29.2 & 15.9 & 20.7 & -0.7 & 13.1 & 4.0 & 6.6 & -17.8 & 6.0 & 12.8 \\
\cline { 2 - 16 } & BT & - & 32.2 & 36.6 & 17.9 & 18.1 & 23.9 & 36.3 & 19.7 & 22.0 & 14.5 & 18.1 & 4.2 & 8.1 & 1.0 & 12.3 & 6.7 \\
\hline
\end{tabular}

Source: own elaboration, based on the data reports published by the Ministry of Finance of the Republic of Moldova. Retrieved from: http://old.mf.gov.md/transparenta/catalog_date_deschise [accessed: 28.01.2019].

Note: For 2014 and 2015 the State Budget does not include transfers made to the the Budget of Territorial Administrative Units.

The trend of spending on education as a share in Gross Domestic Product was a decreasing one, especially from 2009 until 2015, reaching a value of 6.9\% of Gross Domestic Product. These expenditures represent a much higher share in Gross Domestic Product, as compared to the European Union countries, which showed a more stable trend with a value of $4.9 \%$ in 2015. The same situation is observed for other countries taken as a basis of comparison, such as Belgium, the Czech Republic, Sweden, Poland, Finland or Estonia but whose variation in Gross Domestic Product over the years is no greater than 1 to $2 \%$.

In contrast, in the Republic of Moldova this variation is much wider, indicating a lack of stability in the expenditure policy in the field of education throughout all the analyzed years, as well a lack of stability from the Gross Domestic Product side. Therefore, from 1997 to 1999 there was noticed a difficulty of the State to provide the necessary resources for the educational sector. And the highest percentage of $9.4 \%$ in 2009 it is shown that a large portion of resources

1 At the beginning of 2014-2015, as compared to the 2009-2010 academic year, the total number of educational institutions decreased by $11.0 \%$. Simultaneously, the number of preschool education institutions increased by $5.4 \%$ and the number of primary and secondary general education institutions decreased by 10.9\%. [Strategia, 2016].

2 During 2005/2006-2013/2014 both the number of teachers, as well as the number of pupils decreased. Thus, the number of pupils decreased by $32 \%$ and the number of teachers - by $21 \%$. [Strategia, 2016]. 
were directed to the public sector, to education, which might have consequences as well on the private sector, economic growth and other dimensions.

Figure 3. Expenditures on education as the share in Gross Domestic Product in the Euro area (11 countries) and selected countries during 1995-2015 (\%)

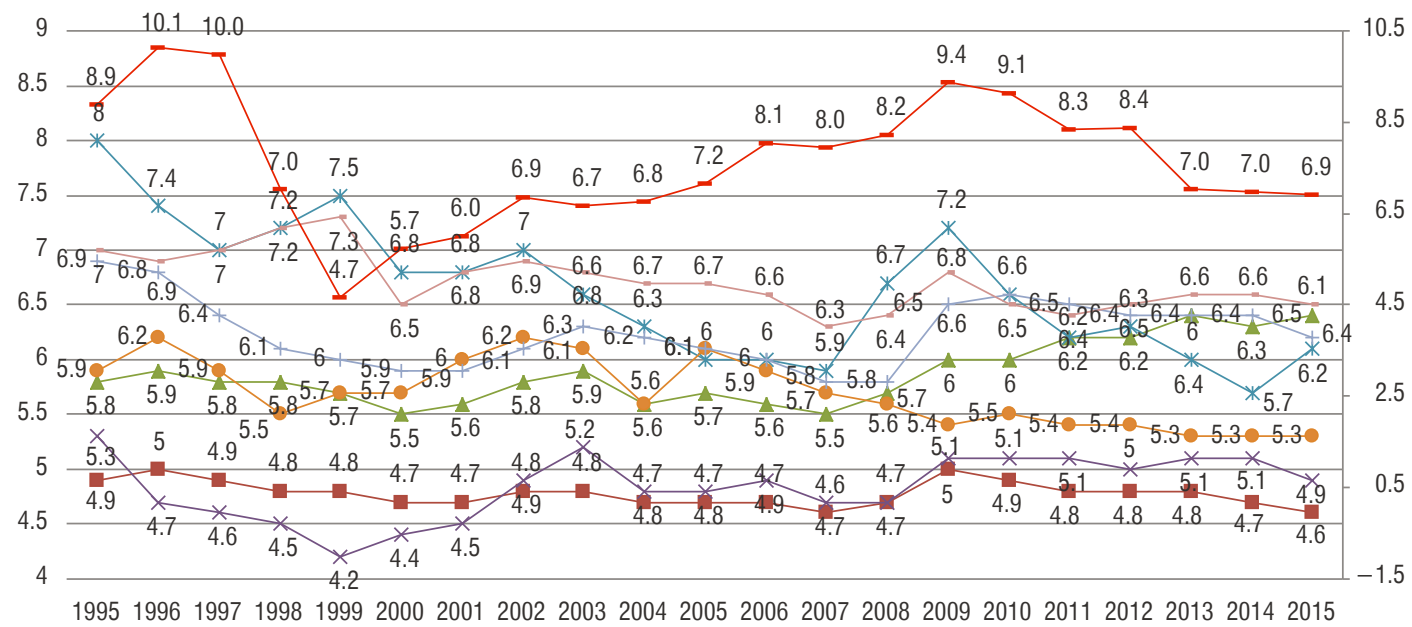

$\rightarrow$-Euro area (11 countries) $\rightarrow$-Belgium $*$ Czechia $*$ Estonia - -Poland + Finland - Sweden - Moldova

Source: own elaboration, based on the data reports published by the Ministry of Finance of the Republic of Moldova. Retrieved from: http://old.mf.gov.md/transparenta/catalog_date_deschise; and the Statistical Year Book of the Republic of Moldova (2002); EUROSTAT data. Retrieved from: https://ec.europa.eu/eurostat/web/government-finance-statistics [accessed: 17.01.2019].

Even though the financial contribution is higher, studies show that compared to other states in the region, the Republic of Moldova is the least efficient in terms of the correlation of funding with the performance of education, and this finding is valid for different levels of the educational sector. In education, Moldova could achieve the same results using a lower share of its revenues [Fala, 2015].

However, there are also a number of issues that have not yet been solved in the field of education, such as [Strategia, 2016]:

a) the inefficiency of the use of financial allocations in the sector;

b) the infrastructure of the classrooms and institutions not adapted to the number of pupils/ students;

c) insufficient expenditures for strengthening the technical and didactic-material basis of the institutions;

d) limited access to quality education services;

e) lack of inclusive education practice.

In this regard, in the Republic of Moldova the Ministry of Education is responsible for developing public policies for the development of the education system and it is responsible for the Medium-Term Budgetary framework. The Ministry has the authority for ensuring the achievement of them [Strategia, 2016]. 
The main sources of financing the expenditures on education are obtained from the State Budget, the Budget of the Administrative Territorial Units and from donor assistance. The revenues in the budgets are obtained from fiscal and non-fiscal revenues, special funds and means revenues. In the same time, it can be mentioned that expenditures are financed by the public and private sector. The private sector presence in financing education is much smaller. ${ }^{3}$ Therefore, the public sector's role in financing education in the country is absolutely crucial.

The analysis shows that public expenditures on education in the Republic of Moldova occupy a major share in total social expenditures and in the Gross Domestic Product. The expenditures instability recorded other the years as an evolution and share in the Gross Domestic Product are influenced by different factors. Moreover, there are a lot of issues to be solved. And just as the main financial resources are obtained from the state, these are crucial for the future development of the educational sector.

\section{The impact of revenues on expenditures for education in the Republic of Moldova}

The theory support for the study includes the unidirectional verification of the initial hypothesis. The initial hypothesis to be tested is that there is no significant impact of revenues on public expenditures in education in the short and long run. Therefore, based on the hypothesis and the research objective in the case of Moldova the investigation follows the function:

$$
E E D_{t}=f\left(\operatorname{Rev}_{t}\right)
$$

where $E E D_{t}$ are expenditures on education and $R e v_{t}$ are revenues.

In order to test the hypothesis, avoid and exclude a spurious regression, the Autoregressive Distributed Lag model is used. The Autoregressive Distributed Lag model is a linear model with a classical disturbance [Greene, 2002]. The Autoregressive Distributed Lag model includes the current and the lagged explanatory variables and one or more lagged values of the dependent variables among its explanatory variables, these are also called dynamic models [Gujarati, 2004]. The general representation of the model takes the form:

$$
y_{t}=a_{0 j}+\sum_{i=1}^{p} a_{j} y_{t-i}+\sum_{i=0}^{q} \beta_{j}^{\prime} x_{t-i}+e_{j t}
$$

where $y=E E D_{t}$ is the dependent variable and $x=\operatorname{Rev}_{t}$ is the independent variable, $e_{i}$-error term, and $\mathrm{p}, \mathrm{q}$ are the lag length.

3 As an example, there can be mentioned that during 2005-2014, over $80 \%$ of the total number of students studied in the public higher institutions [National, 2015]. 
The model in the research follows the specification:

$$
\text { Leed }_{t}=a_{0 j}+\sum_{i=1}^{p} a_{j} \text { Leed }_{t-i}+\sum_{i=0}^{q} \beta_{j}^{\prime} \text { Lrev }_{t-i}+e_{j t},
$$

where $\mathrm{L}$ - is the natural logarithm.

The error correction model follows the relation:

$$
\Delta \text { Leed }_{t}=a_{0}+\sum_{i=1}^{p} a_{1 j} \Delta \text { Leed }_{t-i}+\sum_{i=0}^{q} b_{1 j} \Delta \text { Lrev }_{t-1}+\lambda E C T_{t-1}+e_{t}
$$

where $\lambda$ is the error correction coefficient, which is also called the adjustment coefficient, and ECT is the error correction term.

For the following estimations the appropriate lag for the variable in the current research is based on the information criteria of Akaike Information Criterion $=-1.283250$ and Schwarz Information Criterion $=-1.136213$, and is equal with 2 .

Table 2 describes the samples which were taken in the research analysis for the estimation in testing the initial hypothesis. The sample is retrieved from data reports published by the Ministry of Finance of the Republic of Moldova and the Statistical Year Book of the Republic of Moldova.

Table 2. Descriptive statistics of the public education on expenditures and revenues sample

\begin{tabular}{|c|c|c|c|c|c|c|c|c|c|c|c|c|}
\hline Index & $\begin{array}{l}\text { ్ָ } \\
\sum\end{array}$ & 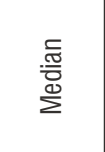 & 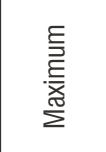 & 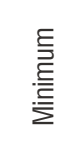 & $\begin{array}{l}\text { वें } \\
\text { 哣 }\end{array}$ & 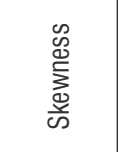 & 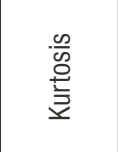 & 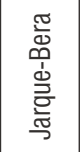 & 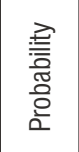 & Е & 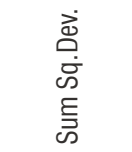 & 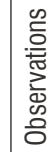 \\
\hline Education & 3650.995 & 2697 & 8462 & 574.5 & 2830.731 & 0.363864 & 1.546462 & 2.312 & 0.315 & 76670.90 & $1.60 \mathrm{e}+0.8$ & 21 \\
\hline \begin{tabular}{|l|} 
Revenues \\
\end{tabular} & 17638.25 & 14527.6 & 43681.1 & 2002 & 14020.64 & 0.471603 & 1.897153 & 1.843 & 0.398 & 370403.2 & $3.93 e+0.9$ & 21 \\
\hline
\end{tabular}
during 1995-2015

Source: own elaboration, based on software estimations.

The data was tested by the Augmented Dickey Fuller test statistics. The probability and test values for the first values Leed and Lrev, which are the logarithmated series for expenditures on education and revenues indicate the presence of a unit root. The test shows that both series become stationary only after their first difference (Table 3).

The Granger causality test confirms that there is a significant (at the $5 \%$ level) unidirectional causality going from revenues to expenditures on education. Thus, it can be said that revenues determine expenditures on education and that past values of revenues are significant in predicting the present value of expenditures. After the initial Ordinary Least Squares method estimation of the variables, it is found that there exists a significant relationship between the variables of expenditures on education and revenues in the short run (Lrev, p-value $=0.0000$, $\mathrm{t}$-Statistic $=33.71033)$. But because the model was considered spurious, further steps in the analysis were performed. 
Table 3. The results of the Augmented Dickey Fuller test for the variables and their first difference

\begin{tabular}{|l|l|c|c|c|c|}
\hline \multicolumn{2}{|c|}{ Variable/Test } & LEd & LRev & $\Delta$ Led & $\Delta$ LRev \\
\hline \multirow{2}{*}{$\begin{array}{l}\text { ADF test } \\
\text { statistic }\end{array}$} & t-Stat. & -0.489543 & -1.644244 & -3.413770 & -4.867444 \\
\cline { 2 - 6 } & Prob. & 0.8731 & 0.4409 & 0.0243 & 0.0012 \\
\hline \multirow{2}{*}{$\begin{array}{l}\text { Test critical } \\
\text { values }\end{array}$} & $1 \%$ & -3.831511 & -3.857386 & -3.857386 & -3.831511 \\
\cline { 2 - 6 } & $5 \%$ & -3.029970 & -3.040391 & -3.040391 & -3.029970 \\
\cline { 2 - 6 } & $10 \%$ & -2.655194 & -2.660551 & -2.660551 & -2.655194 \\
\hline
\end{tabular}

Source: own elaboration, based on software estimations.

The Johansen Contegration Test by the Trace and Max-Eigen statistics shows the existence of one cointegrating equation and that Lrev has a positive impact on Leed on average c.p. ${ }^{4}$ in the long run. The long run relationship between the variables is exhibited and confirmed by performing the Autoregressive Distributed Lag Bound test as well. Thus, it is found that there is the significance of F-statistic value (25.89325) at 5\% significance I(0) $4.94-\mathrm{I}(1) 5.73$, and the $t$ statistic bound test confirms the existence of a long run relationship between the variables, $\mathrm{t}$-statistic $=-7.137803$ at $5 \%$ significance $\mathrm{I}(0)-2.86 \mathrm{I}(1)-3.22$. These results suggest the co-integrating possibility and the use of the error correction model. After the estimation, the consequent tests were run for residuals, model stability and coefficient significance.

Table 4. Residual (R) and Coefficient (C) diagnostics

\begin{tabular}{|c|c|c|c|c|c|c|c|c|c|c|c|c|c|}
\hline & \multicolumn{5}{|c|}{ Heteroskedasticity Test: Breusch-Pagan-Godfrey } & \multicolumn{5}{|c|}{ Breusch-Godfrey Serial Correlation LM test } & \multicolumn{3}{|c|}{ Normality test } \\
\hline \multirow{3}{*}{$\mathrm{R}$} & F-stat. & 0.246542 & Prob. F(5.13 & & 0.9342 & F-stat. & 0.361578 & $\begin{array}{l}\text { Prob. } \\
F(2.11 .)\end{array}$ & & 046 & Jarque & & 1.1611 \\
\hline & $\begin{array}{l}\text { Obs. } \\
{ }^{*} \text { R-squared }\end{array}$ & 1.645612 & $\begin{array}{l}\text { Prob. } \\
\text { Chi-Square }\end{array}$ & & 0.8957 & \multirow{2}{*}{$\begin{array}{l}\text { Obs. } \\
{ }^{*} \text { R-squared. }\end{array}$} & \multirow{2}{*}{1.172037} & \multirow{2}{*}{$\begin{array}{l}\text { Prob. } \\
\text { Chi-Square } \\
(2)\end{array}$} & \multirow{2}{*}{\multicolumn{2}{|c|}{0.5565}} & \multirow{2}{*}{\multicolumn{2}{|c|}{ Probability }} & \multirow{2}{*}{0.5595} \\
\hline & $\begin{array}{l}\text { Scaled } \\
\text { explained SS }\end{array}$ & 0.510656 & \multicolumn{2}{|c|}{$\begin{array}{l}\text { Prob. } \\
\text { Chi-Square (5) }\end{array}$} & 0.9917 & & & & & & & & \\
\hline \multirow{8}{*}{ C } & \multicolumn{5}{|c|}{ Wald test } & \multicolumn{8}{|c|}{ Long run coefficients } \\
\hline & Test Statistic & Value & df & & obability & Variable & Coefficien & Std. Err & & & tatistic & & Prob \\
\hline & \multirow{3}{*}{ F-statistic } & \multirow{3}{*}{14.45567} & \multirow{3}{*}{ (2.13.) } & \multirow{3}{*}{\multicolumn{2}{|c|}{0.0005}} & Leed $(-1)$ & 0.906230 & 0.1234 & & & 340368 & & .0000 \\
\hline & & & & & & Leed $(-2)$ & -0.455657 & 0.1205 & & -3.7 & 80614 & & .0023 \\
\hline & & & & & & Lrev & 0.751157 & 0.1333 & & & 31007 & & .0001 \\
\hline & \multirow{3}{*}{ Chi-square } & \multirow{3}{*}{28.91133} & \multirow{3}{*}{2} & \multirow{3}{*}{\multicolumn{2}{|c|}{0.0001}} & $\operatorname{Lrev}(-1)$ & -0.606414 & 0.16110 & & -3.7 & 64183 & & .0024 \\
\hline & & & & & & Lrev $(-2)$ & 0.400057 & 0.1778 & & & 49839 & & .0424 \\
\hline & & & & & & C & -0.798335 & 0.1726 & & -4.6 & 23597 & & .0005 \\
\hline
\end{tabular}

Source: own elaboration, based on software estimations.

In order to test the residuals for the heteroskedasticity, correlation and normal distribution, the tests Breusch-Pagan-Godfrey, Breusch-Godfrey Correlation LM test and Normality

4 Ceteris paribus (c.p.) - other things held constant. 
test probabilities are analysed. These prove that at a level of $5 \%$ confidence there is a lack of heteroskedasticity and correlation and that the residuals are normally distributed (Table 4, R).

The Wald test (Table 4, C) shows that the coefficients of Lrev, Lrev (-1) and Lrev (-2) are significant at the $5 \%$ and $1 \%$ level, therefore, indicating the existence of a significant relationship in the long run.

Consequently, the final estimation shows that the coefficients are significant. From their significance it is understood that the initial hypothesis is rejected. Thus, the alternative hypothesis can be accepted that there is a significant impact made from revenues on public expenditures on education in the long run.

Figure 4. Stability diagnosis, recursive estimates, Cumulative Sum Test, Cumulative Sum of Squares Test
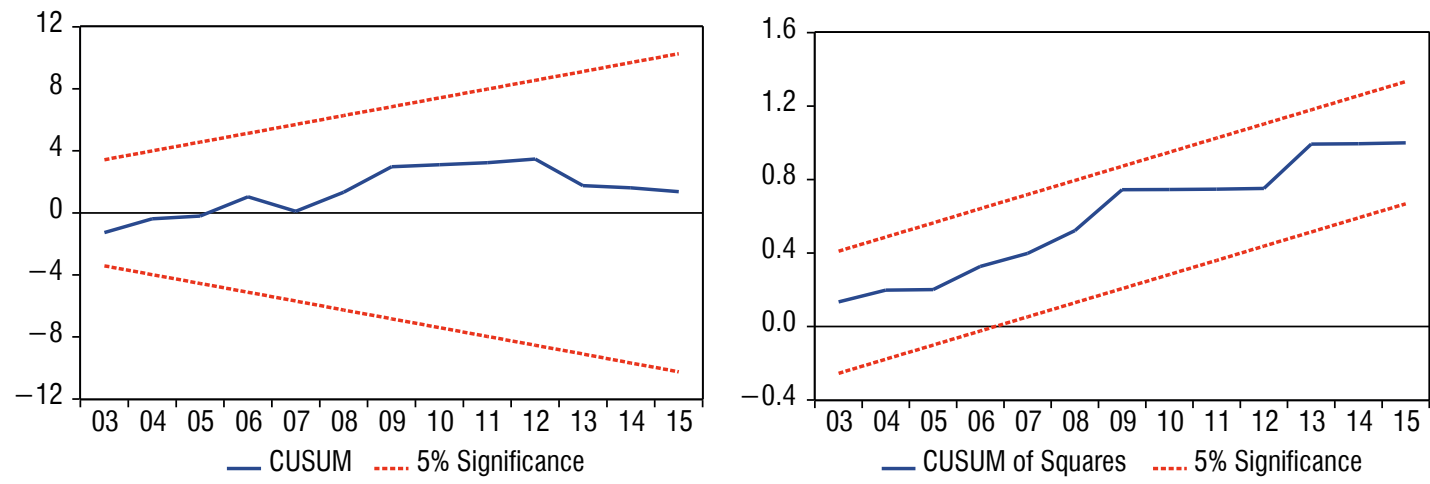

Source: own elaboration, based on software estimations.

The Cumulative Sum Test and the Cumulative Sum of Squares Test show that the model is stable with the critical bounds at the $5 \%$ significance boundary (Figure 3 ). Thus, the model was chosen for the interpretation of the Error Correction Term.

In Table 5 the error correction model result for the dependent variable $\triangle \mathrm{LEED}$ is obtained. This shows the short run estimation for the dependent variable. The coefficients included in the model are statistically significant at the 5\% level and $1 \%$ level, meaning that $\triangle \mathrm{LEED}$ is affected by $\triangle \mathrm{LREV}$ in the short run. From their significance it can be concluded that in the short run a $1 \%$ increase in LREV will lead, on average, c.p. to a $0.75 \%$ increase in LEED. However, the change of $\operatorname{LREV}(-1)$ is associated with a decrease in the dependent variable. The coefficient of error correction term has a negative significant value of -0.549426 . Thereby, it is concluded that the deviation from the long run equilibrium is corrected at a speed of adjustment of $54.94 \%$ within a year, which indicates a stable, medium rate of adjustment to the equilibrium.

Accordingly, it is ascertained that government revenues determine public expenditures on education. This implies that revenues are one of the main determinants of expenditures in education in the short run and in the long run, while other factors are kept constant. 
Table 5. The Error correction model estimation result

\begin{tabular}{|l|c|c|c|c|}
\hline \multicolumn{1}{|c|}{ Variable } & Coefficient & \multicolumn{1}{c|}{ Std. Error } & \multicolumn{1}{c|}{ t-Statistic } & Prob. \\
\hline C & -0.798335 & 0.114483 & -6.973363 & 0.0000 \\
\hline$\Delta$ LEED (-1) & 0.455657 & 0.107597 & 4.234839 & 0.0010 \\
\hline$\Delta$ LREV & 0.751157 & 0.101289 & 7.415952 & 0.0000 \\
\hline$\Delta$ LREV (-1) & -0.400057 & 0.142712 & -2.803241 & 0.0149 \\
\hline ECT (-1) & -0.549426 & 0.081893 & -6.709039 & 0.0000 \\
\hline R-squared & 0.902501 & Mean dependent var & 0.124812 \\
\hline Adjusted R-squared & 0.874644 & S.D. dependent var & 0.168066 \\
\hline S.E. of regression & 0.059505 & Akaike info criterion & -2.584581 \\
\hline Sum squared resid. & 0.049572 & Schwarz criterion & -2.336045 \\
\hline Log likelihood & 29.55352 & Hannan-Quinn criter. & -2.542519 \\
\hline F-statistic & 32.39776 & Durbin-Watson stat & 2.391725 \\
\hline Prob (F-statistic) & 0.000001 & \multicolumn{2}{|}{} & \\
\cline { 1 - 4 } & & &
\end{tabular}

Source: own elaboration, based on software estimations.

\section{Summary}

Expenditures on education in the Republic of Moldova over the years have had a fairly significant share in total spending. In comparison with other countries, they show the presence of instability that is not only due to the change in the Gross Domestic Product but also due to other problems faced by the educational sector.

In order to understand if expenditures on education are defined by government revenues, an analysis of the impact of revenues on expenditures in education was conducted. The Autoregressive Distributed Lag method was used. This has shown that, while other factors are considered to be constant, revenues have a positive impact on expenditures on education in the short run as well as in the long run, with a medium rate of adjustment to the equilibrium in the long run.

Hence the government can make some conclusions in both policy change of the expenditures and revenues, in this way avoiding future deficits created within the National Public Budget. Additionally, it would allow the government to avoid difficulties in financing education, and adjusting the fiscal policy as accurately as possible, considering the future consequences. For the educational sector it is important to consider these results which help to plan and execute expenditures in the most effective way. In this regard the evolution and the forecast of government revenues have to be observed as well.

The limitation of the research is determined by the data availability up to the present time. Due to the changes in the classification of the Ministry of Finance of the Republic of Moldova, a new form of classification was applied beginning with 2016 . Therefore, because 
of inconsistency in the data, the author decided to limit the research up to 2015. This inconsistency also arises in considering the data from the Statistical Year Book of the Republic of Moldova, which is viewed as data limitation for the research.

\section{References}

1. Aregbeyen, O., Insah B. (2013). A dynamic analysis of the link between public expenditure and public revenue in Nigeria and Ghana. Journal of Economics and Sustainable Development, Vol. 4, No. 4.

2. Baghestani, H., McNown, R. (1994). Do revenues or expenditures respond to budgetary disequilibria? Southern Economic Journal, No. 61, pp. 311-322.

3. Barro, R.J. (1979). On the Determination of the Public Debt. Journal of Political Economy, 87, No. 5, pp. 940-971.

4. Buchanan, J.M., Wagner R.W. (1978). Dialogues concerning fiscal religion. Journal of Monetary Economics, No. 4, pp. 627-636.

5. Edita, J.H., Mbazima D. (2008). The causal relationship between government revenue and expenditure in Namibia. Mpra, No. 9154.

6. Fala, A. (2015). Nota analitica privind eficienta cheltuielilor publice pentru sectorul educational. Centrul Analitic Independent EXPERT-GRUP. Chisinau, p. 20.

7. Friedman, M. (1978). The limitations of tax limitations, Policy Review, pp. 7-14.

8. Gujarati, D.N. (2004). Basic econometrics. USA: McGraw-Hill, pp. 362, 656.

9. Greene, W.H. (2002). Econometric Analysis, $5^{\text {th }}$ ed., New Jersey: Prentice Hall, p. 572.

10. Luković, S., Grbić, M. (2014). The Causal Relationship Between Government Revenue and Expenditure in Serbia. Economic Themes, Vol. 52(2), pp. 127-138.

11. Mehrara, M., \& Rezaei, A.A. (2014). The Relationship between Government Revenue and Government Expenditure in Iran. International Journal of Academic Research in Business and Social Sciences, Vol. 4(3).

12. Musgrave, R.A., (1966). Principles of Budget Determination. Public Finance: Selected Readings. New York: Random House, pp. 15-27.

13. Meltzer, A., Richard, S. (1981). A rational theory of the size of the size of government, Journal of Political Economy, Vol. 89, No. 5, pp. 914-927.

14. National Bureau of Statistics of the Republic of Moldova (2015). Education in the Republic of Moldova statistical publication, Chisinau, p. 15. Retrieved from: http://www.statistica.md/ public/files/publicatii_electronice/Educatia/Educatia_RM_2015.pdf [accessed 28.01.2019].

15. Ravinthirakumaran, K. (2011). The Relationship between Government Revenue and Expenditure in Sri Lanka. Conference: ICBI 2011, Colombo.

16. Ordinul (2008). Ordinul ministrului finantelor nr.21 din 20 octombrie 2008. Clasificatia functional a cheltuielilor bugetare. Anexa 2.

17. Ordinul (2015). Ordinul ministrului finantelor nr.208 din 24 decembrie 2015. Norme metodologice privind aplicarea clasificatiei functionale. Anexa 6. 
18. Peacock, A.T., Wiseman, J. (1961). The Growth of Public Expenditure in the United Kingdom. Princeton University Press. Princeton, USA.

19. Peacock, A.T., Wiseman, J. (1979). Approaches to the analysis of Government expenditure growth. Public Finance Review, Vol. 7, pp. 3-23.

20. Strategia (2016). Strategia sectorială de cheltuieli în domeniul educaţiei 2016-2018. Ministerul educatiei, Culturii si cercetarii, pp. 1, 7, 11, 12. Retrieved from: https://mecc.gov.md/sites/ default/files/ssc_2016-2018_text_final.docx [accessed: 27.01.2019]. 